\title{
STUDY OF DRUG COMPLIANCE AMONG DIABETIC PATIENTS
}

\author{
Aruna.T*1 ${ }^{1}$, Srirupa.H*2, Sankara Subramanian ${ }^{2}$, Swathika ${ }^{2}$ \\ ${ }^{1}$ Professor, Dept of Pharmacology, Government Kilpauk Medical College, Chennai, Tamil Nadu, India \\ ${ }^{2}$ Medical Student, Government Kilpauk Medical College, Chennai, Tamil Nadu, India \\ *Corresponding Author email: arunabala511@gmail.com, justmerupa@gmail.com
}

Received 28 May 2015; Review Completed 23 June 2015; Accepted 01 July 2015, Available online 15 July 2015

\begin{abstract}
Diabetes is one of the most common ailments that the general population suffer in today's world. Some are aware about their disturbing blood sugar levels and even understand the importance of appropriate control of the levels with the right medications. Some are aware and yet ignorant due to various causes. This study is aimed at evaluating the drug compliance among type 2 diabetes patients attending the review op of the department of Diabetology, KMCH. A study group of 100 patients attending the review OP were enrolled in the study. The compliance was assessed with the help of their diabetic OP records and a pretested questionnaire was used to further dig into the possible causes for non compliance. The study is broadly based on two main factors leading to non-compliance-causes for patients not getting medicines regularly and causes for patients not taking medicines regularly. These two factors were analyzed based on gender, age, duration of diabetes, co morbid illness, distance etc. The results have shown that $39 \%$ of the patients were not getting the medications regularly, out of which $33.3 \%$ did not get it due to sheer laziness, $38.5 \%$ were forgetful and other serious illness hindered $28.2 \%$ of the patients from getting their medications. It was found that $55 \%$ of the patients took their medications regularly. Among those who took medications regularly, $80.3 \%$ were regular and $15.4 \%$ were not regular in getting medications. Among those who did not take medications regularly, $66.7 \%$ claimed to be forgetful and $46.7 \%$ were non complaint as they did not have adequate knowledge about their medications.33.3\% of the patients did not take it regularly as it gave them a feeling of wellbeing which tempted them to skip doses. Based on these significant data, we will be able to suggest ways and measures to improve the compliance on the treatment aspect. This would increase the desired therapeutic outcome and ultimately, on a broad aspect, it will reduce national health costs.
\end{abstract}

Key words: drug compliance, therapeutic outcome

\section{INTRODUCTION:}

Drug compliance can be defined as reliability of a patient in using a prescribed medication as ordered by the physician. ${ }^{1}$. The importance of this term comes into picture when a person suffering from a chronic ailment is put on long term medications. Such situations come for diseases like diabetes, hypertension, arthritis, tuberculosis etc. Diabetes Mellitus (DM), the most common endocrine disease in the world, is a major global public health issue ${ }^{3}$ As a group, patients with diabetes are especially prone to substantial regimen adherence problems ${ }^{4}$ Noncompliance occurs when the patient forgets or neglects to take the prescribed dosages at recommended times or decides to discontinue the drug without consulting the physician ${ }^{1}$ Effective and successful glucose control requires appropriate and timely use of medication over the entire period of treatment, which is often lifelong. Poor treatment adherence that contributes to suboptimal glycemic control continues to be one of the major barriers to effective diabetes management. Treatment failure is in turn associated with reduced treatment benefits and can have a negative financial burden on both individual patients and the society at large ${ }^{9,10}$. In fact, effective diabetes management often needs coordinated quality services ${ }^{11}$.

The World Health Organization has reported that as many as fifty percent of the patients with chronic diseases do not take their medications as prescribed ${ }^{2}$ Diabetes is a common but easily treatable condition and yet the control in the society is poor due to this major factor of drug compliance. Drug compliance isn't a new challenge. It is mentioned by the Hippocrates many thousands of years ago. It's an old issue but it's very crucial. For this reason, drug compliance has been called the "next frontier in quality improvement" and is an important part of diabetes therapy outcomes.

There are many factors which affect compliance. When they are listed, we will be able to suggest ways and measures to improve the compliance on the treatment aspect.

\section{AIM:}

This study aims to evaluate the drug compliance among type 2 diabetes patients and infer the factors determining drug compliance. 


\section{OBJECTIVE:}

$\checkmark$ To evaluate drug compliance among type 2 diabetic patients.

$\checkmark$ To analyze the causes and consequences of non compliance based on a questionnaire.

\section{METHOD AND MATERIALS:}

Ethical clearance was obtained from Govt. Kilpauk medical college ethical committee.

Study design:Cross Sectional Study

Study Duration: Four weeks

Study Group: One hundred patients attending the review op of the department of Dialectology, KMCH. Informed oral consent was obtained from the patients.

Inclusion criteria: Patients with duration of diabetes 110 years

\section{Exclusion criteria:}

- Patients with acute complications of diabetes

- Duration of DM>15 years

Basic details were collected from the patient. Here patients carry a book which includes the basic demographic data (name, age, place of residence, a passport size photo, duration of diabetes, weight, B.P) the presenting complaints, the investigations ordered, the blood sugar levels checked at various intervals, medications prescribed and complications if any present. The date at which they come to refill the prescription is also mentioned. From these records, compliance was assessed. Further evaluation to find out the causes for non-compliance was assessed by using a pretested questionnaire. Leading questions were not asked at first, the patients were allowed to give their own reason for non compliance, which was noted. Then the common factors contributing to non compliance like negligence, lack of adequate knowledge, forgetfulness, distance from the hospital etc were enquired. The collected data was then analyzed based on two major platforms-one, if the patient got the medications regularly and two, if he took the medicine he got from the hospital. Comparison was made based on various factors such as distance, negligence, other co morbid illness, knowledge about their medications , gender, side effects etc.

\section{RESULTS:}

Among 100 patients enrolled in the study, $61 \%$ got their medications regularly and $55 \%$ were taking their medications regularly. $80.3 \%$ of those getting their medications were taking their medications regularly $(\mathrm{p}<0.001)$. The causes of non compliance were broadly divided into -patient related factors (age, gender, distance from home, dependents, serious illness), therapy related factors (side effects, patients's knowledge, other medications)and psychological factors(negative attitude, laziness, disbelief etc).

The following graph explains the distribution of the study group based on the questions that were put forth to them in the questionnaire. These questions were pertaining to their health profile (if associated illness like hypertension was present), if they were regular in getting/taking medications, various reasons for not getting/taking medications regularly etc.

GRAPH 1: Distribution of study group based on questionnaire

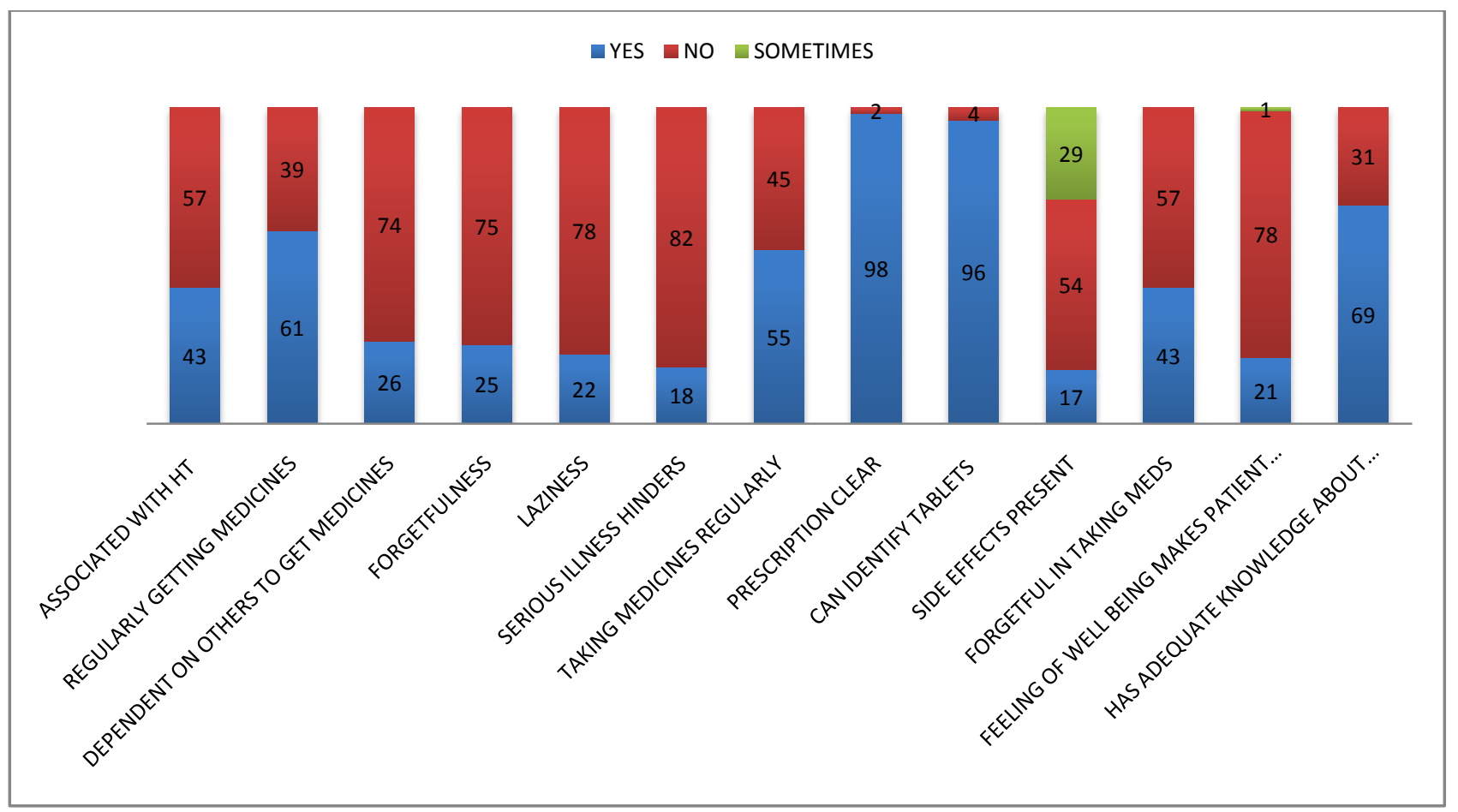


The following table is a comparison of patients' regularity in getting medications from the review OP with various factors. Here we can infer that forgetfulness (38.5\%), laziness (33.3\%)and other serious illness (28.2\%) hinders patients from getting their medications regularly.

TABLE 1: Comparison of patients getting medicines with various causes for not getting medicines

\begin{tabular}{|c|c|c|c|c|c|c|c|c|}
\hline & \multicolumn{4}{|c|}{$\begin{array}{c}\text { Q1.0 Patient regularly getting } \\
\text { medicines }\end{array}$} & \multirow{2}{*}{\multicolumn{2}{|c|}{ Total }} & \multirow[t]{3}{*}{ P-Value } \\
\hline & & \multicolumn{2}{|c|}{ No } & \multicolumn{2}{|c|}{ Yes } & & & \\
\hline & & $\mathrm{N}$ & $\%$ & $\mathrm{~N}$ & $\%$ & $\mathrm{~N}$ & $\%$ & \\
\hline \multirow{3}{*}{$\begin{array}{l}\text { Q2.1 Distance of the hospital } \\
\text { from house }\end{array}$} & $<4 \mathrm{~km}$ & 6 & 15.4 & 11 & 18.0 & 17 & 17.0 & \multirow[t]{3}{*}{0.364} \\
\hline & $4-6 \mathrm{~km}$ & 12 & 30.8 & 24 & 39.3 & 36 & 36.0 & \\
\hline & $>6 \mathrm{~km}$ & 21 & 53.8 & 26 & 42.6 & 47 & 47.0 & \\
\hline \multirow{2}{*}{$\begin{array}{l}\text { Q2.2 Dependent on others for } \\
\text { coming to hospital }\end{array}$} & No & 30 & 76.9 & 44 & 72.1 & 74 & 74.0 & \multirow[t]{2}{*}{0.594} \\
\hline & Yes & 9 & 23.1 & 17 & 27.9 & 26 & 26.0 & \\
\hline \multirow[t]{2}{*}{ Q2.3 Forgetfulness } & No & 24 & 61.5 & 51 & 83.6 & 75 & 75.0 & \multirow[t]{2}{*}{0.013} \\
\hline & Yes & 15 & 38.5 & 10 & 16.4 & 25 & 25.0 & \\
\hline \multirow[t]{2}{*}{ Q2.4 Laziness } & No & 26 & 66.7 & 52 & 85.2 & 78 & 78.0 & \multirow[t]{2}{*}{0.029} \\
\hline & Yes & 13 & 33.3 & 9 & 14.8 & 22 & 22.0 & \\
\hline \multirow[t]{2}{*}{ Q2.5 Serious illness hinders } & No & 28 & 71.8 & 54 & 88.5 & 82 & 82.0 & \multirow[t]{2}{*}{0.034} \\
\hline & Yes & 11 & 28.2 & 7 & 11.5 & 18 & 18.0 & \\
\hline \multicolumn{2}{|l|}{ Total } & 39 & 100.0 & 61 & 100.0 & 100 & 100.0 & \\
\hline
\end{tabular}

The below table 2 compares patients who take medications regularly with various factors. Forgetfulness again plays an important role in non-compliance accounting for $66.7 \%$. Some do not take their medications because they do not have adequate knowledge about it (46.7\%).

TABLE 2: Comparison of patients taking medicines with various causes for not getting medicines

\begin{tabular}{|c|c|c|c|c|c|c|c|c|}
\hline & \multicolumn{4}{|c|}{$\begin{array}{l}\text { Q3.0 Patient taking medicine } \\
\text { regularly }\end{array}$} & \multirow{2}{*}{\multicolumn{2}{|c|}{ Total }} & \multirow[t]{3}{*}{ P-Value } \\
\hline & & \multicolumn{2}{|c|}{ No } & \multicolumn{2}{|c|}{ Yes } & & & \\
\hline & & $\mathrm{N}$ & $\%$ & $\mathrm{~N}$ & $\%$ & $\mathrm{~N}$ & $\%$ & \\
\hline \multirow{2}{*}{$\begin{array}{l}\text { Q4.1 Prescription pattern } \\
\text { clear \& well understood }\end{array}$} & No & 2 & 4.4 & 0 & 0.0 & 2 & 2.0 & \multirow[t]{2}{*}{0.200} \\
\hline & Yes & 43 & 95.6 & 55 & 100.0 & 98 & 98.0 & \\
\hline \multirow{2}{*}{$\begin{array}{l}\text { Q4.2 Identification of tablets } \\
\text { is easy }\end{array}$} & No & 2 & 4.4 & 2 & 3.6 & 4 & 4.0 & \multirow[t]{2}{*}{0.612} \\
\hline & Yes & 43 & 95.6 & 53 & 96.4 & 96 & 96.0 & \\
\hline \multirow{3}{*}{ Q4.3 There is side effects } & No & 20 & 44.4 & 34 & 61.8 & 54 & 54.0 & \multirow[t]{3}{*}{0.124} \\
\hline & Yes & 11 & 24.4 & 6 & 10.9 & 17 & 17.0 & \\
\hline & Sometime & 14 & 31.1 & 15 & 27.3 & 29 & 29.0 & \\
\hline \multirow{2}{*}{$\begin{array}{l}\text { Q4.4 Forgetful in taking } \\
\text { medicines }\end{array}$} & No & 15 & 33.3 & 42 & 76.4 & 57 & 57.0 & \multirow[t]{2}{*}{$<0.001$} \\
\hline & Yes & 30 & 66.7 & 13 & 23.6 & 43 & 43.0 & \\
\hline \multirow{2}{*}{$\begin{array}{l}\text { Q4.5 Patient having adequate } \\
\text { knowledge about the } \\
\text { treatment }\end{array}$} & No & 21 & 46.7 & 10 & 18.2 & 31 & 31.0 & \multirow[t]{2}{*}{0.002} \\
\hline & Yes & 24 & 53.3 & 45 & 81.8 & 69 & 69.0 & \\
\hline \multirow{2}{*}{$\begin{array}{l}\text { Q4.6 Feeling of well being } \\
\text { makes the patient to skip few } \\
\text { doses }\end{array}$} & No & 30 & 66.7 & 48 & 88.9 & 78 & 78.8 & \multirow[t]{2}{*}{0.007} \\
\hline & Yes & 15 & 33.3 & 6 & 11.1 & 21 & 21.2 & \\
\hline \multicolumn{2}{|l|}{$\begin{array}{ll}\text { Total } \\
\end{array}$} & 45 & 100.0 & 54 & 100.0 & 99 & 100.0 & \\
\hline
\end{tabular}


The following graph compares the two important variables of the study-those getting medications regularly with those taking medications regularly.

GRAPH: 2 Comparisons of patients getting medicines regularly with patients taking medications regularly

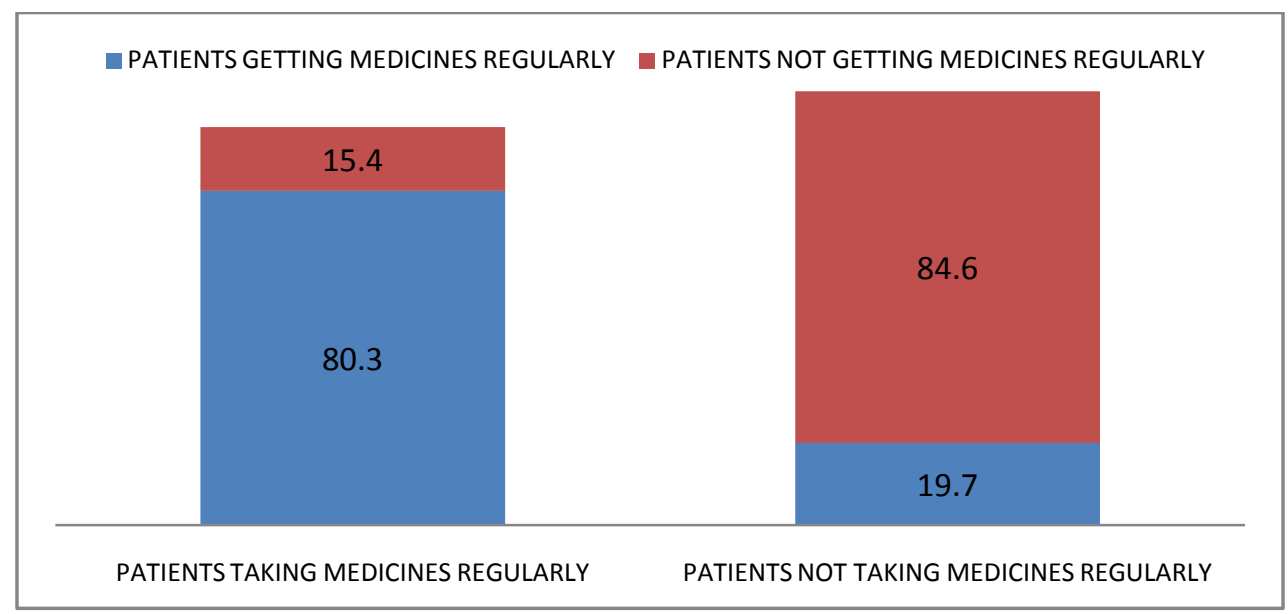

\section{Patient related factors:}

The study had $71 \%$ females and $29 \%$ males. $47 \%$ were staying $>6 \mathrm{~km}$ from the hospital and $26 \%$ were dependent on others to get their medications from the hospital. About $18 \%$ were seriously ill which hindered them from getting medications.

Picture 1: distribution of study population based on distance from hospital Picture 2: distribution of study population based on gender
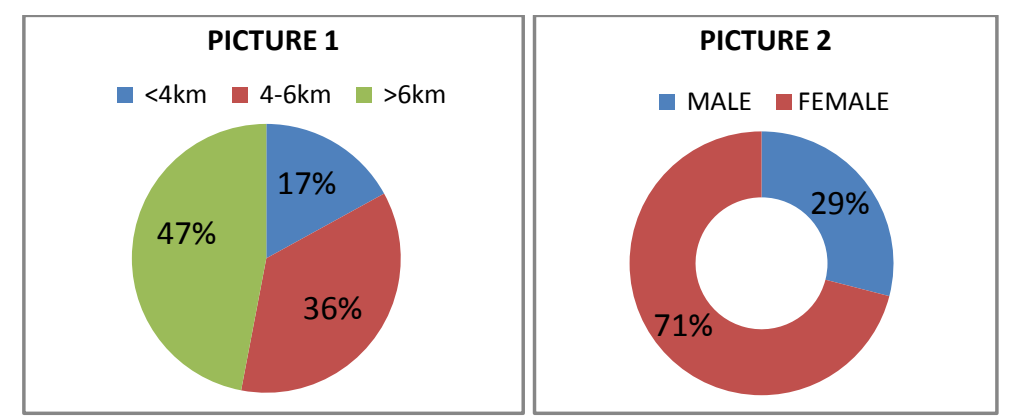

$42.6 \%$ of the people got medication regularly in spite of staying $>6 \mathrm{~km}$ from the hospital. Among regularly getting medications, $72.4 \%$ were males.50.7\% of females did not take regular medications. $27.9 \%$ got medications by depending on others. $28.2 \%$ did not get medications as they were suffering from some serious illness $(\mathrm{p}=0.034)$.

GRAPH 3: Comparison of gender with patients getting and taking medicines regularly

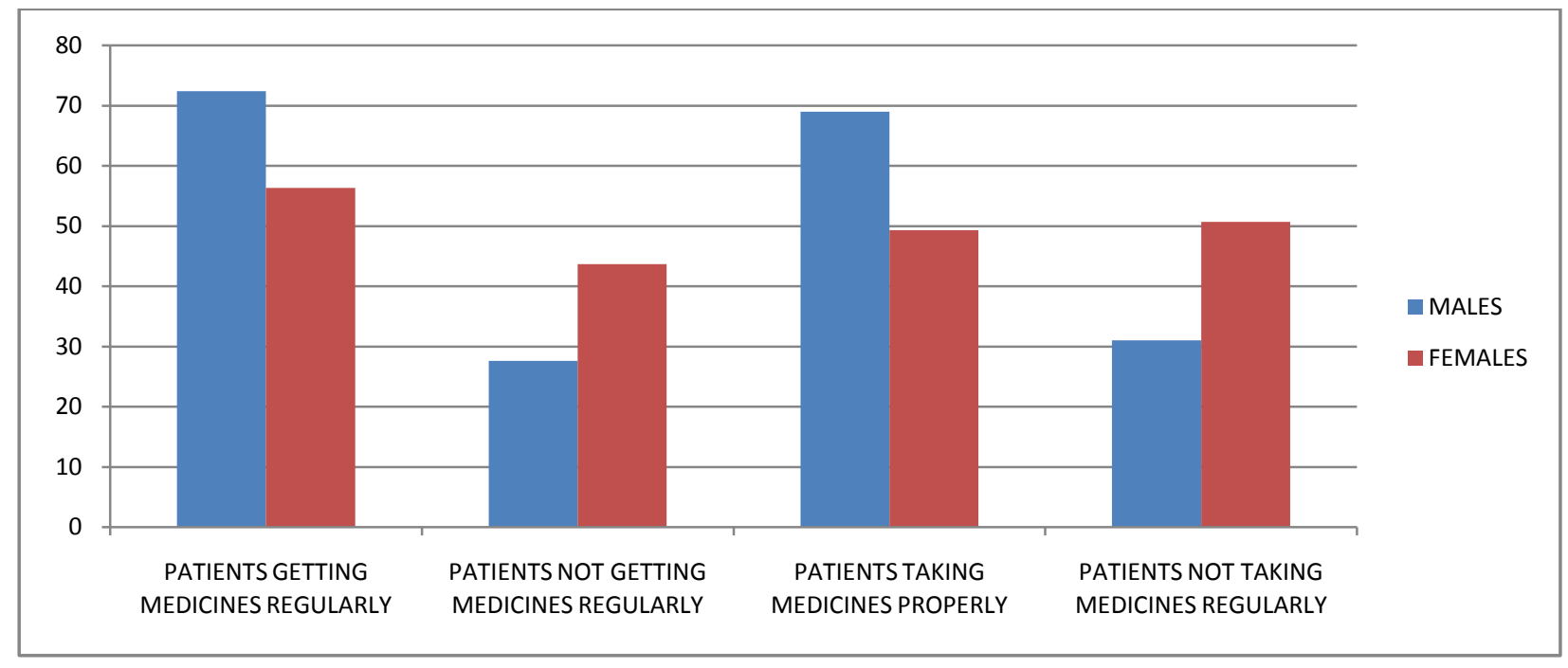




\section{Psychological factors:}

$38.5 \%$ did not get regular medicines due to forgetfulness $(\mathrm{p}=0.013)$ and $33.3 \%$ due to laziness $(p=0.029)$. About $66.7 \%$ did not eat their medications due to forgetfulness $(\mathrm{p}<0.001) .53 .3 \%$ did not take medications in spite of having adequate knowledge about treatment $(\mathrm{p}=0.002)$. Some patients skipped doses when they felt better. This constituted $33.3 \%$ of those who did not takes medicines regularly $(\mathrm{p}=0.007)$.

\section{Therapeutic factors:}

The study group had $43 \%$ with associated hypertension.98\% were able to understand their prescription well and $96 \%$ could identify their tablets easily. $17 \%$ claimed to have experienced side effects. And $69 \%$ claimed to have adequate knowledge about their treatment.

\section{GRAPH 4: Comparison of various psychological and therapeutic factors for patients to take medicines regularly}

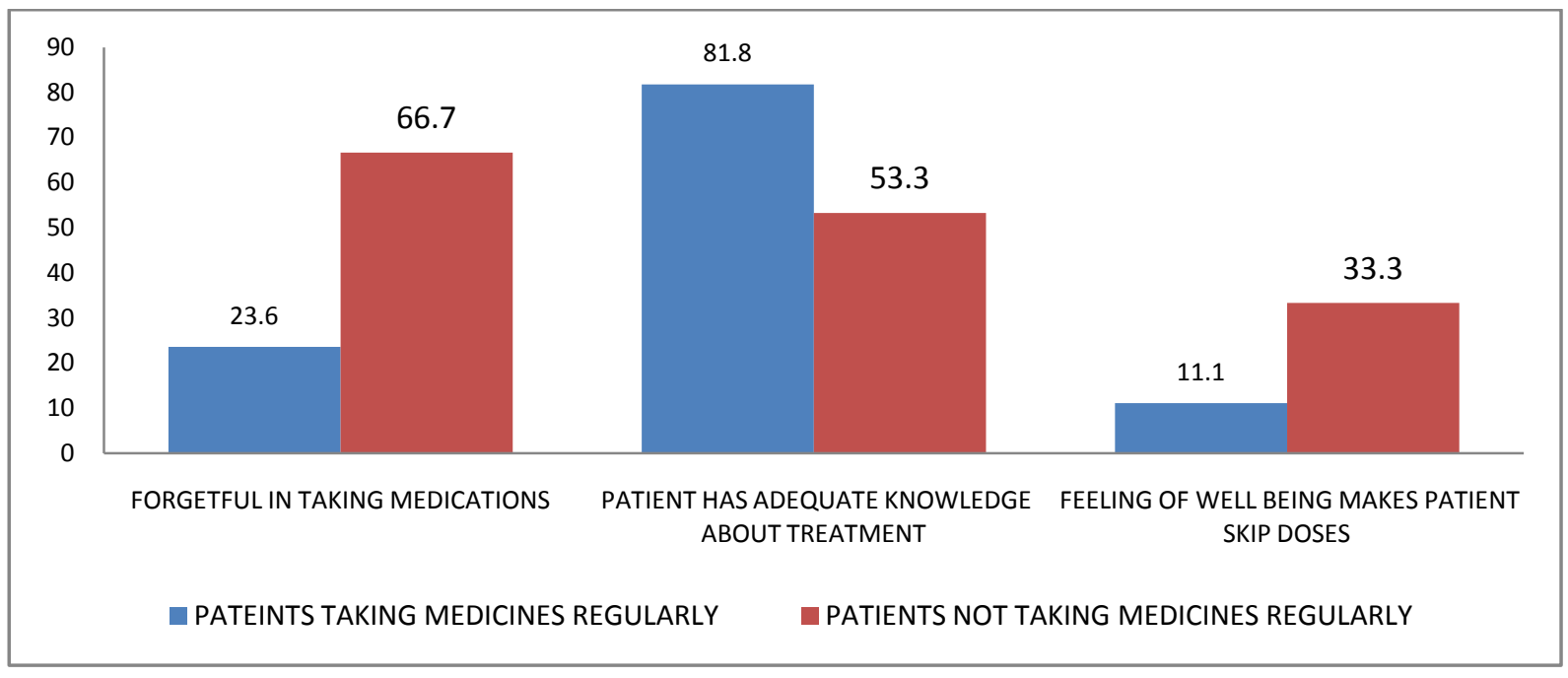

\section{DISCUSSION:}

The rate of non-compliance in patients with chronic diseases in developed countries, on long-term treatment, is on the order of $50 \%$. This could be even higher in developing countries (WHO) ${ }^{14}$. Individuals with low socioeconomic status cannot access education, information, transportation and obtain the required drugs on time. This may increase patients' difficulty to follow diabetes treatment. ${ }^{15}$, 16 (Seligman et al. 2012; Drewnowski and Darmon 2005). If the patient feels that the cost of therapy is a financial burden, the compliance with therapy will definitely be threatened causing low adherence $^{17}$ (Jin et al. 2008). Since most of the patients in our chosen study group have similar difficulties such as transportation, awareness and motivation, we can easily relate these factors to be of utmost importance when it comes to both receiving and consuming the medications regularly. Different studies have shown that adherence to diabetes treatment has been highly varied and may range from 1.4 to $88.0 \%{ }^{5,6,7}$. We have concluded from our study that the main reason for noncompliance is never the same even among the patients of the same age group. Some believe that just by a proper diet plan they can control their disorder. Some patients feel side effects from the prescribed medications might interfere with their day to day life. Some believe in alternate medications such as Ayurveda or siddha for a better cure. As such compliance towards prescribed medications comes down. The World Health Organization has categorized potential reasons for medication nonadherence into 5 broad groupings that include patient, condition, therapy, socioeconomic, and health system-related factors. ${ }^{19-33}$ Examples for each of these categories are detailed in the Table 3 .

Table 3: Reasons for Medication Nonadherence

\begin{tabular}{|l|l|}
\hline $\begin{array}{l}\text { Categories of } \\
\text { Nonadherence }\end{array}$ & Examples \\
\hline Health system & $\begin{array}{l}\text { Poor quality of provider-patient relationship; poor communication; lack of access to healthcare; } \\
\text { lack of continuity of care }\end{array}$ \\
\hline Condition & Asymptomatic chronic disease (lack of physical cues); mental health disorders (eg, depression) \\
\hline Patient & $\begin{array}{l}\text { Physical impairments (eg, vision problems or impaired dexterity); cognitive impairment; } \\
\text { psychological/behavioral; younger age; nonwhite race }\end{array}$ \\
\hline Therapy & Complexity of regimen; side effects \\
\hline Socioeconomic & Low literacy; higher medication costs; poor social support \\
\hline
\end{tabular}


We used a similar approach in our study by highlighting non-compliance due to factors that are patient-centered, therapy-related, or healthcare system - related ${ }^{12}$ The patient-centered factors can be demographic (age, gender, educational level, and marital status) and psychological (patients' beliefs and motivation towards the therapy, negative attitude, patient-prescriber relationship, understanding of health issues, and patient's knowledge). ${ }^{13}$ The therapy-related factors include route of medication, duration of treatment, complexity of treatment, and the side effects of the medicines. The factors associated with the healthcare system include availability, accessibility, and the physician. In addition, it is common for patients to improve their medication-taking behavior shortly before and after an appointment with a healthcare provider, which has been termed "white-coat adherence." 34 Makaryus et $\mathrm{al}^{35}$ found that $<50 \%$ of patients were able to list all of their medications, and even fewer could recount the purpose of their medications at hospital discharge, which suggests that system factors like the educational process at hospital discharge can impact medication adherence after discharge.

Low adherence to prescribed diabetes medications accounts for $30 \%$ to $50 \%$ of treatment failures, leading to worse treatment outcomes and which cause damages to vital organs ${ }^{8}$ One study showed that while diabetic and cardiac patients who take medication correctly have a $7 \%$ death rate; for those who are non-compliant the death rate is $12 \%$.

To date, interventions targeting medication adherence have produced only modest success. In general, unimodal interventions have been less successful than multimodal interventions, because the reasons for nonadherence are often multifactorial. ${ }^{36-40}$ Multimodal interventions have shown the most promise and have improved both adherence and outcomes. For example, Piette et $\mathrm{al}^{41,42}$ randomized veterans with diabetes mellitus to an intervention that consisted of

\section{REFERENCES:}

1) Mosby's Medical Dictionary, 8th edition. S.v. "drug compliance." Retrieved March 252015 from http://medicaldictionary.thefreedictionary.com/drug+compliance

2) Reynolds NR, Testa MA, Marc LG, Chesney MA, Neidig JL, Smith SR, Vella S, Robbins GK, Factors influencing medication adherence beliefs and self-efficacy in persons naive to antiretroviral therapy: a multicenter, cross-sectional study. AIDS Behave 2004; 8(2):141-150 PubMed Abstract

3) Anukote CC. Epidemiology studies of diabetes mellitus in Saudi Arabia -Part 1-screening of 3158 males in King Saud University. J R Soc Health. 1990;110:201-3.

4) Kurtz SMS: Adherence to diabetes regimens: empirical status and clinical applications. Diabetes Educ 16:50 -56, 1990

5) Kalyango JN, Owino E, Nambuya AP, Non-adherence to diabetes treatment at Mulago Hospital in Uganda: prevalence and associated factors. Afr Health Sci, 2008; 8(2):67-73

6) Sankar UV, Lipska K, Mini GK, Sarma PS, Thankappan KR, The adherence to medications in diabetic patients in rural Kerala, India. Asia Pac J Publ Health/Asia-Pacific Academic Consortium for Public Health. 2013.

7) Epub 2013/02/19. doi:10.1177/1010539513475651

8) Raum E, Kramer HU, Ruter G, Rothenbacher D, Rosemann T, Szecsenyi J, Brenner H, Medication non-adherence and poor telemonitoring with interactive voice response technology and weekly nurse feedback and demonstrated improvements in medication adherence and diabetes-related symptoms, as well as a trend for improvement in hemoglobin A1C. Family relationships play an important role in diabetes management. Studies have shown that low levels of conflict, high levels of cohesion and organization, and good communication patterns are associated with better regimen adherence ${ }^{.43}$ Greater levels of social support, particularly diabetes-related support from spouses and other family members, are associated with better regimen adherence ${ }^{44}$ Social support also serves to buffer the adverse effect of stress on diabetes management ${ }^{45}$ from the hospital point of view efforts can be taken to develop proper rapport with the patient win his confidence and counsel him about the importance of his compliance. Motivation is thus the key here. In our study we found that highly motivated patients overcame their problems like distance, associated illness, financial constraints etc. in order to receive their medications from the OPD. Patients who are forgetful/lazy to get/take medications are mostly those who are either unaware about their condition or are ignorant. Such patients must be specifically targeted for proper counseling about their condition, the importance of taking medications that are prescribed.

\section{CONCLUSION:}

Diabetes is a burden which still can be managed appropriately if patients and health care personnel work as a team to ensure drug compliance. Doctors and other health professionals must always monitor how complaint their patients are and dig out the causes of their non-compliance by being open to their apprehensions and helping them overcome it in a positive manner.

Once this is achieved control of diabetes and its efficient management can be implemented at various levels. glycaemic control in patients with type 2 diabetes mellitus. Diabetes Res Clin Pract, 2012, 97(3):377-384

9) Medicine ARftACoP, Medication Adherence Time Tool: Improving Health Outcomes. In: Medication Adherence Clinical Reference. Washington, DC: American College of Preventive Medicine.2011, p 202-466-2044

10) Wroth TH, Pathman DE, Primary medication adherence in a rural population: the role of the patient-physician relationship and satisfaction with care. J Am Board Fam Med, 2006, 19(5):478-486PubMed Abstract

11) DiMatteo MR, Giordani PJ, Lepper HS, Croghan TW, Patient adherence and medical treatment outcomes: a meta-analysis. Med Care 2002, 40(9):794-811

12) Tricco AC, Ivers NM, Grimshaw JM, Moher D, Turner $L$, Galipeau J, Halperin I, Vachon B, Ramsay T, Manns B, Tonelli M, Shojania K (2012) Effectiveness of quality improvement strategies on the management of diabetes: a systematic review and meta-analysis. Lancet 379(9833):22522261PubMed Abstract

13) . Lewis A. Non-compliance: A $\$ 100 \mathrm{bn}$ problem. [Last accessed on 2011 Aug 01];Remington Rep. 19975:14-5. [Last cited on 2010 Nov 20]. Available from:http://www.qu.edu.qa/pharmacy/documents/MEMS_Sem inar_29Sep09-Seminar 
14) . Jing J, Sklar GE, Min Sen Oh V, Chuen LiS. Factors affecting therapeutic compliance: A review from the patient's perspective. Ther Clin Risk Manag. 2008;4:269-86.

15) WHO: A report; Chronic Diseases - Poor compliance of Patients with drug treatment[online] [Last cited on 2010 Oct 02] [Last accessed on 2011 Aug 01]. Available from: http://www.bio-medicine.org/medicine-news/In-ChronicDiseases---Poor-compliance-of-Patients-with-drug-treatment-2097-1/

16) Seligman HK, Jacobs EA, Lopez A, Tschann J, Fernandez A, Food insecurity and glycemic control among low-income patients with type 2 diabetes. Diabetes Care, 2012; 35(2):233238

17) Drewnowski A, Darmon N, The economics of obesity: dietary energy density and energy cost. Am J Clin Nutr, 2005, 82(1 Suppl):265S-273S

18) Jin J, Sklar GE, Min Sen Oh V, Chuen Li S, Factors affecting therapeutic compliance: a review from the patient's perspective. Ther Clin Risk Manag, 2008; 4(1):269-286

19) Abula T, Worku A. Patient noncompliance with drug regimens for chronic diseases in northeast Ethiopia.Ethiop J Health Dev. 2001;15:185-92.

20) World Health Organization. 2003. Adherence to Long-Term Therapy: Evidence for Action. Available at: http://www.who.int/chp/knowledge/publications/adherence_int roduction.pdf. Accessed May 27, 2009.

21) National Council on Patient Information and Education. Enhancing Prescription Medicine Adherence: A National Action Plan. Available at: http://www.talkaboutrx.org/. Accessed September 3, 2008.

22) Bardel A, Wallander MA, Svärdsudd K. Factors associated with adherence to drug therapy: a population-based study. Eur J Clin Pharmacol. 2007; 63: 307-314.

23) Hyre AD, Krousel-Wood MA, Muntner P, Kawasaki L, DeSalvo KB. Prevalence and predictors of poor antihypertensive medication adherence in an urban health clinic setting. J Clin Hypertens (Greenwich). 2007; 9: 179-186.

24) Mochari H, Ferris A, Adigopula S, Henry G, Mosca L. Cardiovascular disease knowledge, medication adherence, and barriers to preventive action in a minority population. Prev Cardiol. 2007; 10: 190-195.

25) Charles H, Good CB, Hanusa BH, Chang CC, Whittle J. Racial differences in adherence to cardiac medications. J Natl Med Assoc. 2003; 95: 17-27.

26) Gazmararian JA, Kripalani S, Miller MJ, Echt KV, Ren J, Rask K. Factors associated with medication refill adherence in cardiovascular-related diseases: a focus on health literacy. J Gen Intern Med. 2006; 21: 1215-1221.

27) Rieckmann N, Gerin W, Kronish IM, Burg MM, Chaplin WF, Kong G, Lespérance F, Davidson KW. Course of depressive symptoms and medication adherence after acute coronary syndromes: an electronic medication monitoring study. J Am Coll Cardiol, 2006; 48:2218-2222.

28) Rieckmann N, Kronish IM, Haas D, Gerin W, Chaplin WF, Burg MM, Vorchheimer D, Davidson KW. Persistent depressive symptoms lower aspirin adherence after acute coronary syndromes. Am Heart J. 2006; 152: 922-927.

29) Gehi A, Haas D, Pipkin S, Whooley MA. Depression and medication adherence in outpatients with coronary heart disease: findings from the Heart and Soul Study. Arch Intern Med. 2005; 165: 2508-2513.

30) Kim MT, Han HR, Hill MN, Rose L, Roary M. Depression, substance use, adherence behaviors, and blood pressure in urban hypertensive black men.Ann Behav Med. 2003; 26: 24 31.

31) Bane C, Hughes CM, McElnay JC. The impact of depressive symptoms and psychosocial factors on medication adherence in cardiovascular disease.Patient Educ Couns. 2006; 60: 187-193.

32) Wang PS, Bohn RL, Knight E, Glynn RJ, Mogun H, Avorn J. Noncompliance with antihypertensive medications: the impact of depressive symptoms and psychosocial factors. J Gen Intern Med. 2002; 17: 504-511.

33) Carney RM, Freedland KE, Eisen SA, Rich MW, Jaffe AS Major depression and medication adherence in elderly patients with coronary artery disease. Health Psychol. 1995; 14: 88-90.

34) Kronish IM, Rieckmann N, Halm EA, Shimbo D, Vorchheimer D, Haas DC, Davidson KW. Persistent depression affects adherence to secondary prevention behaviors after acute coronary syndromes. J Gen Intern Med. 2006; 21: 1178-1183.

35) Osterberg L, Blaschke T. Adherence to medication. N Engl J Med. 2005;353: 487-497

36) Makaryus AN, Friedman EA. Patients' understanding of their treatment plans and diagnosis at discharge. Mayo Clin Proc. 2005; 80: 991-994.

37) Haynes RB, Ackloo E, Sahota N, McDonald HP, Yao X. Interventions for enhancing medication adherence. Cochrane Database Syst Rev. 2008 Apr 16:CD000011.

38) Heneghan CJ, Glasziou P, Petra R. Reminder packaging for improving adherence to self-administered long-term medications. Cochrane Database Syst Rev. 2006 Jan 25: CD005025.

39) Schroeder K, Fahey T, Ebrahim S. How can we improve adherence to blood pressure-lowering medication in ambulatory care? Systematic review of randomized controlled trials. Arch Intern Med. 2004; 164: 722-732.

40) McDonald HP, Garg AX, Haynes RB. Interventions to enhance patient adherence to medication prescriptions: scientific review. JAMA. 2002; 288:2868-2879.

41) Kripalani S, Yao X, Haynes RB. Interventions to enhance medication adherence in chronic medical conditions: a systematic review. Arch Intern Med. 2007; 167: 540-550.

42) Piette JD, Kraemer FB, Weinberger M, McPhee SJ. Impact of automated calls with nurse follow-up on diabetes treatment outcomes in a Department of Veterans Affairs Health Care System. Diabetes Care. 2001; 24: 202-208.

43) Piette JD. Interactive voice response systems in the diagnosis and management of chronic disease. Am J Manag Care. 2000; 6: 817-827.

44) Delamater AM, Jacobson AM, Anderson BJ, Cox D, Fisher L, Lustman P, Rubin R, Wysocki T: Psychosocial therapies in diabetes: report of the Psychosocial Therapies Working Group. Diabetes Care24 : 1286-1292,2001

45) Glasgow RE, Toobert DJ: Social environment and regimen adherence among type II diabetic patients. Diabetes Care 11:377 -386, 1988

46) Griffith LS, Field BJ, Lustman PJ: Life stress and social support in diabetes: association with glycemic control. Int $\mathbf{J}$ PsychiatryMed20: 365-372, 1990. 